\section{China Calls for Smarter Standards for Its World-Class Universities}

\section{QIANG ZHA}

Qiang Zha is associate professor at the Faculty of Education, York University, Toronto, Canada. E-mail: qzha@edu.yorku.ca.

Criner hina has launched a new stage of its world-class university campaign. On October 24, 20I5, China's State Council officially promulgated a blueprint that explicitly and exclusively spells out details as to China's world-class university ambition, including a timetable. Among other things, this document aims to break the boundaries that fragment existing "excellence" schemes (e.g., Projects 985, $2 \mathrm{II}$ and 2OII), and reconcile and consolidate resources in order to boost this effort.

\section{TOP the Global Ran KIngs by the mid-2000S}

For this goal, the document sets the following timetable: by 2020 , a number of Chinese universities and subject areas are to achieve world-class standing; by 2030, more universities and subject areas will enjoy world-class status, and some of them will top league tables of the global rankings; by 2050 , China will excel as a system in terms of leading universities and fields of study in the whole world.

The central and local governments pledge to support this endeavor by concentrating resources on selected universities. Starting in 2016 , there will be a new cycle for competitive funding every five years, which is significantly longer than the current funding cycle of Project 985 (three years), and may allow the winning universities more flexibility and freedom to use the granted resources. Resources will flow to those universities that excel in the competition in terms of performance, strengths, and distinction. At the outset of this new effort, the ministries of finance and education announced on November I7, 20I5 the establishment of a world-class university and field incentive funding scheme for the centrally affiliated universities. This fund consolidates funding previously scattered among programs established for comparable purposes, and is explicitly mandated to foster excellence measured by world standards among those universities.

Compared to previous exercises, this policy initiative emphasizes transparency and requires competition for resources, in an effort to improve funding efficiency and results. It places equal importance on world-class institutions and subject areas, which potentially includes a lot more universities than those previously selected on excellence schemes (especially under Project 985). This new initiative serves to challenge the prestigious status held by those universities, and hence evokes a rigorous competition toward fulfilling the goal in an efficient manner.

\section{What Distinguishes Chinese Universities as World- CLASS PLAYERS?}

Yet, this endeavor will not be easy to accomplish. Arguably, the debate about which criteria define a world-class university remains unresolved. Albeit, the global rankings remain the most powerful illustration of who can claim world-class standing-those institutions in the top 50 or roo spots in the league tables. Those global rankings rely heavily on research inputs and outputs to sort universities into a "world order," and this seems to be the logic and strategy behind China's robust venture to be a country hosting a concentration of world-class universities.

The past decade has already witnessed resources being poured into China's top universities to reinforce research infrastructure and capacity. In 20I4, the richest 30 Chinese universities recorded an average of total expenditure of US\$I billion, which is only outmatched by the United States at the system level, but probably unmatched elsewhere, if one takes into account the short time frame during which the university funding reached this level. Only five years ago, the group that enjoyed this level of funding comprised no more than five Chinese universities. A big chunk of the spending directly benefited research or research-related endeavors, given that Chinese universities generally spend less for staff compensations and student services, relative to their peers in the west.

The newly-released UNESCO Science Report: Towards 2030 demonstrates that China has moved to the second place in global R\&D expenditure, with a global share of 20 percent, following the United States (28\%), but ahead of the European Union (I9\%) and Japan (ı०\%). Additionally, China has enjoyed a surge in the generation of knowledge. Chinese publications now represent 20 percent of the world total, compared to 5 percent only io years ago. The Nature Index (a database that tracks contributions to articles published in a group of highly selective science journals) records that the recent growth of China's output in the index has overshadowed that of any other nation, a 37 percent rise of high-quality research papers between 2012 and 2014 (vs. a $4 \%$ drop for the United States over the same period). Needless to say, China's leading universities were the force behind this leap in the country's R\&D performance. As early as in 2007 , Chinese university researchers were reported placing 85 percent of the country's publications in international journals. 


\section{China Needs Its Own Standards to Measure University SUCCESS}

All this may reflect significant improvement at individual universities, but not necessarily for the system as a whole. In other words, a number of individual Chinese universities climbing to top ranking positions is one story, and the Chinese system as a global leader is another. Put explicitly, individual universities can hardly make a game changer, but a university model may. It is important to note that the success of Western systems in global comparisons leveraged not only the performance of individual universities, but also (and more importantly) the strength of a normative model. The British university model featured the notion of liberal education; the German model advanced the idea of research for the sake of creating knowledge; and the US model combined both of these and highlighted the university's role of social service.

\section{...China's State Council officially pro- mulgated a blueprint that explicitly and exclusively spells out details as to Chi- na's world-class university ambition, in- cluding a timetable.}

Then, how might a new Chinese higher education system be defined? The new blueprint requires top universities to pursue world-class standing, while developing "Chinese characteristics." With this added ambiguity, China will need to develop its own standards for the world-class university endeavor, which support both a global role for Chinese universities and cultural distinctiveness. Whether there is a Chinese or Confucian model of the university now is debatable, but Chinese universities, with unprecedented support from a strong state, indeed reflect a distinctiveness that is different from their Western peers. For instance, Chinese universities seek to articulate strategic planning with national and local development agendas, and address national and local needs. This type of politicized social engagement often absorbs considerable resources, be they human or material. The current global rankings are not able to measure these contributions and, as a result, the contributions of Chinese universities to social and economic development are systematically underestimated and undervalued. Furthermore, since lifting the restrictions on study abroad and (literally) encouraging it some 30 years ago, China has suffered from a huge brain drain, which now hovers at an estimate of over three million Chinese knowledge workers residing abroad. Yet in recent years, Chinese universities began to benefit from the process of brain circulation.

Arguably, there is no other system with such an ambitious national agenda for academic development and competitiveness, especially over such an extended time span. There is essentially no international indicator that captures the significance of this agenda or timeline. China's success may be significant, but not necessarily in the way that will move its universities into more competitive positions in the current global rankings. The government's intentions reflect quite different agendas at the same time, and would benefit from explicit "Chinese standards" to help establish a clearer direction for higher education development in the country.

\section{Chinese Higher Education: "Glass Ceiling" and "Feet of Clay"}

\section{Philip G. Altbach}

Philip G. Altbach is research professor and founding director of the Center for International Higher Education at Boston College. E-mail: altbach@bc.edu.

C hina's impressive higher education accomplishments have masked some significant barriers to the ascent of Chinese universities to the top rungs of global academe, as well as some significant problems at the bottom of the system. Key structural problems create a "glass ceiling" that may affect further improvements in the international rankings. This discussion follows Rui Yang's “Toxic Academic Culture in East Asia," an insightful analysis in the Winter (2016) issue of International Higher Education, that emphasized some deep challenges facing universities in the region, from corruption to influence peddling in academic appointments.

The focus in China has been on a small but important number of research universities, mainly the institutions that are part of the well-known 985 and 2II programs, that pumped billions of US dollars into a limited number of top Chinese universities. Without any doubt, this investment has created significant research capacity and world-class infrastructure at these top universities, and will probably yield impressive results in the coming decades. Yet, mainland China has only two universities in the top 200 of the Times Higher Education global rankings-compared to three for 